\title{
Introduction: The City as a Multifaceted and Dynamic Constitutional Entity
}

Citation for published version (APA):

de Visser, M., Hirsch Ballin, E., Van der Schyff, G., \& Stremler, M. (2021). Introduction: The City as a Multifaceted and Dynamic Constitutional Entity. In E. Hirsch Ballin, G. Van der Schyff, M. Stremler, \& M. De Visser (Eds.), European Yearbook of Constitutional Law 2020: The City in Constitutional Law (pp. 113). TMC Asser Press. European Yearbook of Constitutional Law Vol. 2 https://doi.org/10.1007/978-946265-431-0_1

Document status and date:

Published: 01/01/2021

DOI:

10.1007/978-94-6265-431-0_1

Document Version:

Accepted author manuscript (Peer reviewed / editorial board version)

\section{Please check the document version of this publication:}

- A submitted manuscript is the version of the article upon submission and before peer-review. There can be important differences between the submitted version and the official published version of record.

People interested in the research are advised to contact the author for the final version of the publication, or visit the DOI to the publisher's website.

- The final author version and the galley proof are versions of the publication after peer review.

- The final published version features the final layout of the paper including the volume, issue and page numbers.

Link to publication

\footnotetext{
General rights rights.

- You may freely distribute the URL identifying the publication in the public portal. please follow below link for the End User Agreement:

www.umlib.nl/taverne-license

Take down policy

If you believe that this document breaches copyright please contact us at:

repository@maastrichtuniversity.nl

providing details and we will investigate your claim.
}

Copyright and moral rights for the publications made accessible in the public portal are retained by the authors and/or other copyright owners and it is a condition of accessing publications that users recognise and abide by the legal requirements associated with these

- Users may download and print one copy of any publication from the public portal for the purpose of private study or research.

- You may not further distribute the material or use it for any profit-making activity or commercial gain

If the publication is distributed under the terms of Article $25 \mathrm{fa}$ of the Dutch Copyright Act, indicated by the "Taverne" license above, 


\title{
Chapter 1 \\ Introduction: The City as a Multifaceted and Dynamic Constitutional Entity
}

\author{
Maartje De Visser, Ernst Hirsch Ballin, Gerhard van der Schyff and Maarten Stremler
}

\subsection{The City as an Undervalued Constitutional Trope}

The inaugural edition of this Yearbook was devoted to a veritable classic in constitutional law, viz. judicial power. As one of the constituent elements of the horizontal trinity of powers, the judiciary has long captured the attention of scholars, politicians and the general public alike across time and across space. ${ }^{1}$ Matters have been rather different for the government entity that is at the heart of the Yearbook's second imprint: the city. In our modern-day states, cities are associated with the lowest rung of the national power structure, and this hierarchically inferior status has in turn given rise to the perception that cities do not make for a particularly alluring or meaningful object of constitutional study. In this regard, law appears to be somewhat out of step with the other branches of the social sciences, which hold cities in considerably higher regard. ${ }^{2}$ There are good reasons for doing so.

Historically, the antecedents of cities as a governance unit predate Montesquieu's famous conceptualisation of the judiciary as part of the trias politica by several centuries. Some of the most important concepts that have shaped the organisation of our nation-states have their roots in the city states (poleis) of ancient Greece. Athens is typically considered the world's first democracy, in which all free adult males took part in the city's political life. ${ }^{3}$ Each had the right to vote on proposed new laws during public assemblies held at the agora, infusing Athenian democracy with the kind of deep enfranchisement that contemporary efforts for more participatory government seek to replicate (though within the confines of our representative democratic systems). The Greek city states also conceived of the idea of citizenship, with the entitlements and duties that flowed from this status still forming the core of national citizenship. Participation in political decision-making was a privilege reserved to citizens on an equal basis ${ }^{4}$ who acquired that status through birth, not wealth, and which entitled them to the full protection of the government, including against enslavement by fellow citizens. In turn, Greek citizens owed political allegiance to the polis: they could not show loyalty to any other power and were duty-bound to take an interest in the affairs of the city-state on the pain of punishment. ${ }^{5}$ Fastforwarding to the twenty-first century, we see several international organisations, including the EU and the UN, pushing towards more decentralisation and subsidiarity in state administration - a move that is strongly inspired by the belief that lower-level State units like cities are particularly well-suited to induce participatory governance. To give expression to and operationalise the democratic quality attributed to city governance the acceptance of a form of 'city citizenship' may be required. ${ }^{6}$ To the extent that this concept would be understood as not

\footnotetext{
${ }^{1}$ See e.g. Hamilton 1788; Kelsen 1928; Ginsburg and Versteeg 2014.

${ }^{2}$ See e.g. Glaeser 2012; Schwab et al 2017; Sassen 2005.

${ }^{3}$ Mitchell 2019.

${ }^{4}$ It should be noted that Athenian democracy was premised on limited citizenship: women, slaves and foreigners were denied citizenship and there was no route for non-citizens to acquire this status.

5 This is reflected in Aristotle's well-known proposition in his Politics that 'Man is by nature a political animal', according to which the highest degree of human happiness is realised through political partnership with fellow citizens. For a succinct overview, see plato.stanford.edu/entries/aristotle-politics.

${ }^{6}$ On this notion, see amongst others, Bauböck 2019; Pedroza 2019.
} 
only normatively, but also as legally significant, the relationship with national citizenship will need to be worked out. ${ }^{7}$

Sociologists conceive of cities as spaces of high density (where individuals live in close proximity to one another), high diversity in terms of cultural, ethnic and religious make-up, high economic complexity and high socio-economic impact. These characteristics have not only been observed in modern cities: during the interbellum, the celebrated Belgian scholar Henri Pirenne demonstrated that the medieval city already exhibited a social vitality that resulted in an explosion of economic activity and a remaking of 'the whole social order ... along more flexible, more active and more varied lines'. ${ }^{8}$ The dynamism inherent in the sociological understanding of the city looks set to be amplified as a result of an urbanisation process that started in earnest with the first industrial revolution and has continued apace since then. At the midway point of that revolution, one in ten Europeans lived in a city. Less than a century later, the continent's urban population had tripled. By 1950, the world's urban population stood at 751 million, rapidly rising to 4.2 billion in 2018 , according to United Nation figures. This number is projected to increase by more than 50 per cent by $2050 .{ }^{9}$ This means that cities will be home to the majority of the world's population, for whom city administrations become, in many respects, their quintessential governing units. ${ }^{10}$

As front-line entities, city administrations are moreover at the vanguard in dealing with a host of challenges with a constitutional flair: ${ }^{11}$ creating a healthy, clean living environment; addressing social segregation across ethnicity, class, age or nationality ${ }^{12}$ respecting the dignity and securing the basic human needs of (illegal) migrants that flock to cities; harnessing technology for social good - such as facilitating access to government services or better protecting communities from unwanted behaviour ${ }^{13}$ - while minimising the bad - like leaving those without digital literacy skills behind or disregarding legitimate privacy concerns. ${ }^{14}$ Consequently, cities are also increasingly appearing at the international stage.

This Yearbook is situated among a budding body of works that aims to restore cities as deserving of serious scholarly attention in the field of (comparative) constitutional law. ${ }^{15}$ Its premise is that rather than constitutional backwaters, cities are exciting tropes for research as this is where the constitutional rubber hits the road. The contributions to this Yearbook showcase the kaleidoscopic range of issues at play, from the positioning of cities within the wider organisation of the State as well as their role as prime sites where individuals encounter or otherwise engage with State power.

\subsection{Cities within National Power Structures}

The signing of the Treaty of Westphalia in 1648 is often celebrated as the birth of the Nation State, yet it should be remembered that the arrival of this new model for the organisation of society came at the expense of untrammelled city power. Europe's cities were repositioned as among the lowest constituent units within the overall state structure, with circumscribed

\footnotetext{
${ }^{7}$ Cf. Stahl 2020.

${ }^{8}$ Pirenne 2014, p 102.

${ }^{9}$ United Nations Department of Economic and Social Affairs (2019).

${ }^{10}$ Arguing that city administrations can rise to the occasion: Barber 2013 and Emanuel 2020.

${ }^{11}$ E.g. Katz and Nowak 2018; Inman 2009.

12 See e.g. Florida 2018; Trounstine 2018.

${ }^{13}$ See e.g. Ranchordas (2019).

${ }^{14}$ Van Zoonen 2016.

15 See Hirschl 2020; Massaro and Milczarek-Desai 2018; Bendor 2013; and Pieterse 2014.
} 
competences and responsibilities. ${ }^{16}$ This design of territorial governance has similarly found favour in other parts of the world, often through colonisation. ${ }^{17}$

While the general placement of cities in the overall power structure can be said to be an archetypal feature of constitutional design, the precise institutional arrangements may vary considerably from one country to the next. Cities may also be subject to differentiated treatment within the confines of a single State, with some enjoying a greater measure of autonomy than what is otherwise the norm. Such an approach is perhaps most noticeable in federalised regimes, but also decentralised or unitary States can single out one or a few cities for special treatment. Even in the absence of a legally territorially pluralist approach, we should realise that the simple label 'city' captures units that are united in diversity as far as size, socio-economic relevance and actual political clout are concerned. This heterogeneous state of affairs is itself the product of a complex and dynamic interplay among historical, political, economic, geographical and human factors. Matters are compounded by the minimalist treatment that most constitutions reserve for cities: a quick database search reveals that about two-thirds of the texts currently in force do not mention the term at all. Among those that do, the constitutional recognition may be limited to the identification of the capital city. This legal state of affairs makes it necessary to identify and scrutinise relevant small-c constitutional rules in order to arrive at a good understanding of the relationship between cities and other echelons of government.

Clearly, then, inquiries into the vertical distribution of power can be demanding, which arguably helps explain their relative dearth. At the same time, they are important and increasingly so. A careful inventory of the legal-political status quo is necessary for legal theorists to formulate a coherent theory of the city and its position in the constitutional order; for comparatists to identify genuine similarities and differences across jurisdictions; and for constitutional scholars generally to evaluate whether existing arrangements are still fit for purpose.

A number of contributors to this edition of the Yearbook have engaged in the hard work that mapping exercises require. Taken together, their accounts showcase and contextualise the immense varieties in national constitutional design just alluded to. What is more, they identify in what respects and why existing arrangements are in need of reform as well as the form that improvements should ideally take.

The Dutch constitutional arrangements as chartered in Chap. 2, written by Wytze van der Woude, are strikingly simple. The basic legal structure of big cities like Amsterdam and Rotterdam is no different from that of the smallest municipalities, but the regulatory framework is not particularly rigid or prescriptive. This allows for bottom-up differentiation. Nevertheless, the need to establish intermunicipal forms of cooperation within urban agglomeration between the core-city and suburban municipalities has repeatedly provoked proposals for differentiation between large urban and smaller municipalities. Against this backdrop, Van der Woude reflects on the need to constitutionally demarcate cities vis-à-vis other types of local authorities. So far, none of the proposals for constitutional differentiation has been accepted. Consequently, Dutch cities continue to rely on the inherent flexibility of the existing arrangements - a state of affairs that Van der Woude considers defensible as well as desirable.

Gert-Jan Leenknegt takes a comparative perspective in Chap. 3 and considers how Amsterdam, Hamburg and Paris fare in terms of constitutional autonomy. Barring the partial exception of the three cities-Länder in Germany, cities are treated according to a single, national and general structure of constitutional and legal arrangements in the Netherlands, Germany and France. This might seem anachronistic, given our contemporary reality in which big cities increasingly occupy a distinct place in the urban government landscape. Leenknegt accordingly offers two hypotheses in thinking about the design of a dedicated constitutional law framework

\footnotetext{
${ }^{16}$ Cf. Frug 1980.

${ }^{17}$ See e.g. Harding and Sidel 2015.
} 
for big cities. On the one hand, local and regional governance law arrangements could be usefully combined to strengthen the autonomy of big cities. On the other hand, the governance of complex and diverse big cities could be improved by decentralising democratic structures within cities.

Complexity is a challenge that Johan Lievens and Karel Reybrouck also grapple with in their examination of the constitutional arrangements pertaining to Brussels in Chap. 4. Excluding the EU, the territory of Brussels is subject to six governments with formal legislative power. The authors argue that this city's complicated constitutional structure impedes efficient and coherent metropolitan governance. Belgium's constitutional design reflects not so much what is suitable for Brussels, but instead reflects a constitutional vision for the rest of the country, which does not always answer to the city's needs. To address this situation, Lievens and Reybrouck propose a range of reforms with the aim of further developing Brussels' status within Belgium's overall federal structure and improving the accessibility of this structure for the general public.

In Chap. 5, Alberto Cruces Burga and Andrés Devoto Ykeho explore the ventures of governance in the metropolitan region of Lima within Peru's decentralising constitutional arrangements. Rapid population growth in cities like Lima has created considerable challenges in the fulfilment of metropolitan functions. The authors focus their analysis on the effects of Lima's subdivision into various autonomous districts. They show how this intra-city segmentation is detrimental to the provision of public services, and may cause spending inefficiencies. In response, Burga and Ykenho argue that a wholesale re-evaluation of the country's vertical design is needed as a first step in Peru coming to terms with its new urban reality.

Questions of fragmentation and differentiation are also at the heart of Eric Ip's analysis of the relationship between China and its two most well-known subnational entities, viz. Hong Kong and Macau, in Chap. 6. These cities are presently the only territories to enjoy the status of special administrative region (SAR) within China's unitary state structure, which translates into a significantly higher degree of autonomy than that available to other territorial divisions. Ip traces the origins of this asymmetric arrangement and its legal expression in the constitutional charters of Hong Kong and Macau. In so doing, he also reconstructs the factors that help explain why each of these SARs enjoys a dramatically different relationship with China, despite largely similar legal frameworks. Ip's analysis shows the importance of crafting grants of local autonomy in such a way that these match the actual political will and expectations of all sides, all the more so when ideology issues are involved.

The extent to which regional and local autonomy is accepted in a given constitutional system is arguably a reflection of the state's constitutional identity. By way of example, in Germany three cities - Berlin, Hamburg and Bremen - have been accorded the constitutional rank of a Land (a party-sovereign state), which can partially be rationalised as in line with the country's Germany's federal character that in turn is an integral part of German constitutional identity. Indeed, the 'eternity clause' enshrined in Article 79 (3) of the Grundgesetz (Basic Law) declares constitutional changes infringing upon the federal constitutional structure inadmissible. ${ }^{18}$ However, as Jörg Fedtke's contribution in Chap. 7 shows, the precise constitutional status of cities also reflects the constitutional history of a country. Fedtke's contribution, which focuses on the extraordinary constitutional setting of the three German citystates, moreover illustrates how cities can simultaneously be part of different forms of cooperative governance in a multi-layered system.

In contrast to Germany, national unity in a territorial sense is part and parcel of China's constitutional identity, as confirmed in Article 3 of the PRC Constitution. This document

\footnotetext{
${ }^{18}$ See further Calliess 2020, p 156.
} 
accordingly does not contain any provisions that would stand in the way of possible future reductions of the actual regional or local autonomy. ${ }^{19}$ The special status for the autonomous city-regions Hong Kong and Macao is merely the result of agreements concluded with the former colonial powers, that moreover have a limited time span. Whereas cities in classic unitarian states may enjoy significant leeway in shaping their own policies and governing those living within city limits, the state's constitutional identity neither precludes nor stimulates a higher degree of autonomy for cities, irrespective of their size or practical salience.

\subsection{Cities and Citizens}

As local government units, cities are the principal sites where citizenship is put into practice through the invocation of fundamental rights and the performance of civic duties. Public squares, urban parks and streets are typical venues for the physical exercise of the rights to speech and assembly in the form of demonstrations, political campaign rallies and other modes of communication. The democratic rights for citizens are closely related to their physical presence in the local context. In Europe, this has resulted in the extension of such rights to certain categories of non-nationals of the encompassing, as required by EU $\mathrm{law}^{20}$ and the (poorly accepted) Council of Europe Convention on the Participation of Foreigners in Public Life at Local Level (1992). ${ }^{21}$ In this sense, democratic governance practices in cities may herald an understanding of the legal concept of citizenship that is more suitable for the realities of the growing size of city populations all over the world through immigration, be it from rural hinterlands and from other countries. ${ }^{22}$ As 'cities have a long history as the primary locus of allegiance and integration into the polity', a municipal and urban view on citizenship is gaining influence. ${ }^{23}$ Beyond enabling the use of civil-political rights, cities have an important role in providing urban dwellers and those living in their hinterland with access to amenities that are indispensable for the enjoyment of socio-economic and cultural rights. The ongoing Covid-19 pandemic has thrown this role of cities into sharp relief.

The idea that cities have a part to play in the operationalisation of the full suite of fundamental rights has led to the articulation of a 'right to/through the city', ${ }^{24}$ defined by the World Charter for the Right to the City as 'the equitable usufruct of cities within the principles of sustainability, democracy, equity, and social justice. It is the collective right of the inhabitants of cities, in particular of the vulnerable and marginalised groups, that confers upon them legitimacy of action and organisation, based on their uses and customs, with the objective to achieve full exercise of the right to free self-determination and an adequate standard of living. ${ }^{25}$ This right is increasingly inscribed and fleshed out in dedicated charters of city rights

\footnotetext{
19 Zhai 2019.

${ }^{20}$ See art. 40 of the Charter of Fundamental Rights of the European Union: 'Every citizen of the Union has the right to vote and to stand as a candidate at municipal elections in the Member State in which he or she resides under the same conditions as nationals of that State.'

${ }^{21}$ See art. 6(1) of this Convention: 'Each Party undertakes, subject to the provisions of Article 9, paragraph 1, to grant to every foreign resident the right to vote and to stand for election in local authority elections, provided that he fulfils the same legal requirements as apply to nationals and furthermore has been a lawful and habitual resident in the State concerned for the 5 years preceding the elections.'

${ }^{22}$ Hirsch Ballin 2014.

${ }^{23}$ Maas 2017, p 661.

${ }^{24}$ Originally coined by French philosopher Henri Lefebvre in his Le Droit à la ville (1968), revived and adapted by Harvey 2003.

${ }^{25}$ Signed during the World Social Forum under the auspices of the UN in 2005 (Porto Alegre). The full text of the Charter can be found at: http://hic-gs.org/document.php?pid=2422.
} 
that the protagonists themselves have drawn up, ${ }^{26}$ usually without involvement of the national government: at present, Ecuador is the only country that recognises this right in its constitution. ${ }^{27}$ Such assertions of authority may be a welcome development for urban populations, but also raise challenging questions about the management as well as desirability of a multi-layered system for rights protection within a nation-state.

Several contributions in this Yearbook explore the complex interplay between cities, rights and citizens. Natalia Angel-Cabo, in Chap. 8, shows how cities are fundamental arenas for contesting rights. Focusing on the realisation of socio-economic rights in the Global South, she examines how judicial decisions regarding constitutional rights are received, discussed and implemented 'on the ground', i.e. in the social reality of cities. In particular, she considers the potential and limitations of judicial experimentalism, an approach in which courts do not make final judgments directly, but instead seek solutions through dialogue and negotiation with the authorities and populations concerned.

In Chap. 9, Marius Pieterse sketches the relationship between the right to a city and the right to health, resulting in the right to healthy city. His essay explains that the physical features of cities influence the mental and physical health of their inhabitants, adding that many of the determinants for this fall under the jurisdiction of cities to some or other extent. Although constitutional frameworks in this regard differ widely, it becomes increasingly clear that urban governance must not be neglected in addressing health related issues such as the Covid-19 pandemic or climate change. Pieterse concludes that by making a conscious effort in applying their powers, cities can contribute to realising the right to health.

Whereas the right to the city is normally discussed in relation to the physical urban space, the digitalisation of society focuses attention on the interplay between material spaces and the digital realm. Chapter 10 by Jack Lee examines the prospects for a digital right to the city in Singapore, with particular reference to the ability for people to come together in support of public causes as well as make online statements the veracity of which is questionable. Lee shows how a generous understanding of 'public interest' on the part of the authorities is likely to stand in the way of the constitutional recognition of a right to the city, be it in its digital or traditional guise. At the same time, his analysis also draws attention to the responsibilities that individuals must adhere to if and when such a right becomes accepted.

The exercise of speech and assembly rights take on special importance in relation to the people's involvement in political decision-making. It is common to observe distinct voting preferences and patterns across urban and rural areas, which can have major ramifications for a country's overall political trajectory. Against this reality, Paul Burgess in Chap. 11 invites us to reflect on the circumstances in which and conditions under which participatory decisionmaking would be a sensible choice. His point of departure is the Brexit referendum, in which Greater London as the UK's quintessential bastion of power was unable to secure the outcome favoured by the majority of its inhabitants - and arguably also by the national political elites whose offices are located in this metropolis. Burgess argues that calibrated resource to direct democracy should be evaluated positively from a Rule of Law perspective, by providing a counterbalance to the particular incentives or preferences of urban powerhouses on matters of national importance.

\footnotetext{
${ }^{26}$ Such as the Global Charter - Agenda for Human Rights in the City and the European Charter for the Safeguarding of Human Rights in the City, both adopted by the United Cities and Local Governments (UCLG) network.

${ }^{27}$ Ecuador Constitution, art. 31.
} 


\subsection{Cities and the International Arena}

While international law continues to operate the legal fiction that the State is a monolithic entity, a closer look reveals that cities are increasingly flexing their - derivative - international muscles. Many are stepping up to implement the growing corpus of international commitments that the national government has accepted, notably in high-profile areas such as environment protection, migration or human rights. ${ }^{28}$ Sometimes this is done pursuant to delegated authority; on other occasions, cities voluntarily assume responsibility for international rights and obligations, typically when the national government has shown less appetite to do so. Recall, by way of illustration, the way in which US cities rallied around the objectives encapsulated in the Paris Agreement on Climate Change in the wake of the Trump administration announcing its intention to withdraw from that pact. ${ }^{29}$ For their part, international organisations have begun to realise that partnering cities can be attractive in the delivery of their objectives. Thus, UNHabitat has developed a pro-decentralisation agenda that is inspired by anticipated democracy gains, ${ }^{30}$ while the World Bank promotes fiscal decentralisation and privatisation to advance economic growth. ${ }^{31}$ On a related note, in a recent article, Martha Davis explores the relation between 'the vibrant international movement to ensure that local governments recognise, participate in, and comply with, human rights norms' and 'the smart cities movement'. ${ }^{32}$ As she notes, the application of new technologies by the city administration in providing public services and ensuring regulatory oversight ought to be compliant with human rights norms.

A stronger presence of cities in the international arena may have a positive impact on the effectiveness of good governance initiatives. The picture is arguably more mixed when viewed through a domestic constitutional perspective frame: allowing cities to play a constructive role may upset the conventional arrangements pertaining to the allocation of State powers and responsibilities. However, since treaties between states are being supplemented or even to some extent replaced by soft law like the global compact on migration, ${ }^{33}$ legal development is no longer exclusively tied to the sovereign authority of states and moving 'beyond formal law'. ${ }^{34}$ Cities have entered the international arena, especially in response to the emergence of new public tasks like prevention of climate crises. ${ }^{35}$

It is precisely this role of cities that Barbara Oomen, Moritz Baumgärtel and Elif Durmus discuss in Chap. 12, with reference to their view on international responsibility. Distancing themselves from national laws and policies in the light of human rights norms and sustainable development goals, e.g. as 'Accelerating Cities' 'Solidarity Cities' or Sustainable Cities, cities display a new level of constitutional self-consciousness. The authors investigate how courts respond to manifestations of such self-consciousness in cases from Germany, Turkey, France, the Netherlands and Spain in which national governments had become embroiled in conflict with cities over the constitutional division of responsibilities. This chapter lays the foundations for comparative research focused on the dynamics of local authorities and

\footnotetext{
${ }^{28}$ See Gerald et al 2006; Blank 2006.

29 '461 US Climate Mayors commit to adopt, honor and uphold Paris Climate Agreement goals' (statement from the climate mayors in response to President Trump's withdrawal from the Paris Climate Agreement), available at: http://climatemayors.org/actions/paris-climate-agreement/.

${ }^{30}$ See UN-Habitat, 'International Guidelines on Decentralization and Access to Basic Services for all' (2009) and the general microsite on local governments and decentralisation at https://unhabitat.org/topic/localgovernments-and-decentralisation.

${ }^{31}$ See the general World Bank microsite at: http://www1.worldbank.org/publicsector/decentralization/what.htm.

32 Davis 2020, p 974.

${ }^{33}$ Global Compact for Safe, Orderly and Regular Migration (Marrakech 11 December 2018), endorsed by the General Assembly of the United Nations on 19 December 2018, A/RES/73/195

${ }^{34}$ Krisch 2019, p 698.

${ }^{35}$ See e.g. Nijman 2011; Aust and du Plessis 2019.
} 
on the question how their position is shaped by an invocation of international law in general, and human rights in particular.

More than thirty years after the European Charter of Local Self-Government took effect in 1988, Karl Kössler and Annika Kress in Chap. 13 examine to what extent European cities indeed qualify as self-governing policy-makers and policy-takers. They develop three criteria on the basis of which various types of special cities in Germany, Austria and Italy are selected and compared. It becomes apparent that self-government as policy-making is undermined by a lack of financial resources when measured against the mandates of cities. As policy-takers, the three types of special cities are involved in national and sub-national legislation through local government associations, and opportunities for specific representation regarding matters with a local impact. To fully rise to the occasion, special cities in each of the jurisdictions covered would have to exceed the standards set by the Charter. This, the authors conclude, however poses little difficulty given that the Charter only sets minimum standards. These relatively low benchmarks are not altogether surprising, as the Charter seeks to accommodate the diverse arrangements in a wide variety of states. The corollary of privileging inclusivity to such an extent is however that it devalues the Charter as an instrument to achieve legal harmonisation.

\subsection{Constitutional Law in the Age of the City}

With the growth of cities, our expectations and aspirations for urban living grow as well, at times even exceeding the standard to which we hold states: cities should be paragons of good governance, eminently liveable spaces ${ }^{36}$ smart as well as sustainable. ${ }^{37}$ The meaning to be ascribed to and practical realisation of these ideals requires a conversation in which constitutional law must feature more prominently than it has to date. This Introduction has identified three sets of relations that await unpacking: that between cities and other institutions in the national constitutional architecture; that between cities and their inhabitants; and that between cities and international organisations. A study of the nature and quality of those relationships may yield new, different views on how to conceptualise cities in legal terms. What is the fundamental purpose of a city: an engine for economic growth, a loyal agent of the State, a place for individual and collective development or yet something else? As Richard Schragger has noted, 'how we think about what a city $i$ s alters what we think the city can do'. ${ }^{38}$ Several pertinent follow-up questions present themselves. Can subnational constitutionalism be extended beyond federations and beyond the regional tier? Should cities (continue to) be grouped together with and treated akin to other local territorial units? If differentiated treatment in law is called for, what form should this take and how can States ensure that bedrock constitutional values are not waylaid in the course of cities' legal emancipation? Two contributions to the Yearbook provide a preview of what the future of constitutional law in the age of the city may look like.

The reasons for cities' invisibility in scholarly works and legal-constitutional arrangements are elucidated in vivid terms in the contribution to this Yearbook by Ran Hirschl. In Chap. 14, he identifies a state-centric view that has endured over centuries and across jurisdictions as the key culprit. States are weary of becoming locked in an internal competition for power with subnational units, notably as far as large cities are concerned. Moving beyond diagnosis, Hirschl suggests that it is precisely the megacity as the ultimate manifestation of urban agglomeration that must become a new territorial paradigm. Noteworthy are also the references to attitudes by states in the Global South, several of which now countenance the

\footnotetext{
${ }^{36}$ E.g. Davern M et al, 'How do we create liveable cities?' (The Conversation, 7 December 2015); Kaal 2011.

${ }^{37}$ Cf. Goal 11 of the UN Sustainable Development Goals.

${ }^{38}$ Schragger 2016, p 10.
} 
empowerment of large metropolises (albeit subject to ultimate control by the centre), which offer the tantalising prospect of legal transplants going from East to West for a change.

In Chap. 15, Erika Arban posits that cities in general should be understood as unique socio-economic and political spaces distinct from municipalities and local governments. This would enable more and more creative experimentation with novel modes of governance that evokes the idea of regulatory competition and a 'race to the top'. What is more, recognising the special character of cities should bode well for their legal and economic (re-)empowerment. This should be an attractive value proposition for those invested in overcoming the gap between aspirations and capabilities that currently plagues especially larger cities.

There is much work to be done to arrive at a better account of the constitutional positioning of cities; fortunately, there is also much to work with. This Yearbook aims to enlarge the corpus of legal academic writings that address one of the most dynamic areas in the field of constitutional law and in the process, whet intellectual appetites for others to join the fray. 


\section{References}

Aust H, du Plessis A (eds) (2019) The Globalisation of Urban Governance: Legal Perspectives on Sustainable Development Goal 11. Routledge, Abingdon

Barber B R (2013) If Mayors Ruled the World: Dysfunctional Nations, Rising Cities. Yale University Press, New Haven

Bauböck R (2019) Cities vs States: Should Urban Citizenship be Emancipated from Nationality? https://globalcit.eu/cities-vs-states-should-urban-citizenship-be-emancipatedfrom-nationality Accessed 31 August 2020

Bendor J (2013) Municipal Constitutional Rights: A New Approach. Yale Law \& Policy Review 31:389-431

Blank Y (2006) The City and the World. Columbia Journal of Transnational Law 44:875-939

Calliess C (2020) Constitutional Identity in Germany: One for Three or Three in One? In: Calliess C, van der Schyff G (eds) Constitutional Identity in a Europe of Multilevel Constitutionalism. Cambridge University Press, Cambridge, pp 153-181

Davis M F (2020) Get Smart: Human Rights and Urban Intelligence. Fordham Urban Law Journal 47:971-991

Emanuel R (2020) The Nation City: Why Mayors Are Now Running the World. Knopf, New York

Florida R (2018) The New Urban Crisis: How Our Cities Are Increasing Inequality, Deepening Segregation, and Failing the Middle Class - and What We Can Do About It. Basic Books, New York

Frug G E (1980) The City as a Legal Concept. Harvard Law Review 93:1057-1154

Gerald E, Frug G E, Barron D J (2006) International Local Government Law. The Urban Lawyer 38:1-62

Ginsburg T, Versteeg M (2014) Why Do Countries Adopt Constitutional Review? Journal of Law, Economics, \& Organization 30:587-622

Glaeser E (2012) Triumph of the City: How Our Greatest Invention Makes Us Richer, Smarter, Greener, Healthier and Happier. Penguin Books, London

Hamilton A (1788) Federalist No. 78 And the Power of the Judiciary

Harding A, Sidel M (eds) (2015) Central-Local Relations in Asian Constitutional Systems. Hart Publishing, Oxford

Harvey D (2003) The Right to the City. International Journal of Urban and Regional Research 27:939-941

Hirsch Ballin E (2014) Citizens Rights and the Right to Be a Citizen. Brill Nijhoff, Leiden

Hirschl R (2020) City, State: Constitutionalism and the Megacity. Oxford University Press, Oxford

Inman R P (ed) (2009) Making Cities Work: Prospects and Policies for Urban America. Princeton University Press, Princeton

Kaal H (2011) A Conceptual History of Liveability. City 15:532-547

Katz B, Nowak J (2018) The New Localism: How Cities Can Thrive in the Age of Populism. Brookings Institution Press, Washington, D.C.

Kelsen H (1928) La guarantie juridictionnelle de la constitution (La justice constitutionnelle). Revue du droit public XXXV:197-257

Krisch N (2019) Pluralism. In: d'Aspremont J, Singh S (eds) Concepts for International Law: Contributions to Disciplinary Thought. Edward Elgar, Cheltenham/Northampton, pp 691707

Lefebvre H (1968) Le Droit à la ville. Antropos, Paris

Maas W (2017) Multilevel Citizenship. In: Shachar A, Bauböck R, Bloemraad I, Vink M (eds) The Oxford Handbook of Citizenship. Oxford University Press, Oxford, pp 644-668 
Massaro T M, Milczarek-Desai S (2018) Constitutional Cities: Sanctuary Jurisdictions, Local Voice, and Individual Liberty. Columbia Human Rights Law Review 50:1-108

Mitchell T N (2019) Athens: A History of the World's First Democracy. Yale University Press, New Haven

Nijman J (2011) The Future of the City and the International Law of the Future. In: Muller S, Zouridis S, Frishman M, Kistemaker L (eds) The Law of the Future and the Future of Law. Torkel Opsahl Academic EPublisher, Oslo, pp 213- 229

Pedroza L (2019) Citizenship Beyond Nationality - Immigrants' Right to Vote Across the World. University of Pennsylvania Press, Philadelphia

Pieterse M (2014) Development, The Right to the City and the Legal and Constitutional Responsibilities of Local Government in South Africa. South African Law Journal 131:149-177

Pirenne H (2014) Medieval Cities: Their Origins and the Revival of Trade - Updated Edition. Princeton University Press, Princeton

Ranchordas S (2019) Nudging Citizens Through Technology in Smart Cities. International Review of Law, Computers \& Technology 33:210-229

Sassen S (2005) The Global City: Introducing a Concept. Brown Journal of World Affairs $\mathrm{XI}: 27-43$

Schragger R (2016) City Power: Urban Governance in a Global Age. Oxford University Press, Oxford

Schwab C, Bouckaert G, Kuhlmann S (eds) (2017) The Future of Local Government in Europe - Lessons from Research and Practice in 31 Countries. Nomos Verlagsgesellschaft, Baden-Baden

Stahl K A (2020) Local Citizenship in a Global Age. Cambridge University Press, Cambridge Trounstine J (2018) Segregation by Design: Local Politics and Inequality in American Cities. Cambridge University Press, Cambridge

Van Zoonen L (2016) Privacy Concerns in Smart Cities. Government Information Quarterly 5:472-480

United Nations Department of Economic and Social Affairs (2019) World Urbanization Prospects - the 2018 Revision. United Nations, New York. https://population.un.org/wup/Publications/Files/WUP2018-Report.pdf Accessed 31 August 2020

Zhai H (2019) The Constitutional Identity of Contemporary China: The Unitary System and Its Internal Logic. Brill Nijhoff, Leiden 